\title{
Bank Selection Criteria in the Iranian Retail Banking Industry
}

\author{
Apena Hedayatnia \\ School of Management, University of Tehran \\ No.22, Street 16/2, Kaje shomali Avenue, Golha Sq., Tehran 1431843468, Iran \\ Tel: 98-912-387-6523 E-mail: apena.hedayatnia@gmail.com \\ Kamran Eshghi (Corresponding author) \\ School of Management, University of Tehran, Tehran, Iran \\ $\&$ \\ STE 2708, 15 Greenview Avenue, North York, Toronto, Ontario M2M 4M7, Canada \\ Tel: 1-647-718-3671Ｅ-mail: k_eshghi@yahoo.ca
}

Received: June 11, 2011

Accepted: July 26, 2011 Published: December 1,2011

doi:10.5539/ijbm.v6n12p222

URL: http://dx.doi.org/10.5539/ijbm.v6n12p222

\begin{abstract}
Iranian retail banks need to identify criteria which bank customers consider when they select a bank in order to plan their marketing strategies and survive in an intense competition that exist in this industry. This study designed to examine the bank selection criteria being employed by bank customers in Iran. A total of 798 customers (55.7 percent male and 44.3 percent female) served as a sample for the study. 38 selection factors extracted from relevant literature and interviews with five bank officials. Factors analysis is used to extract important selection criteria and Friedman analysis ranks the factors according to their importance. Findings show that the important factors determining customers' selection are: quality of services and new banking methods, innovation and responsiveness of bank, friendliness of staff and confidence in manager, price and cost, staff attitudes and convenience of bank location and services.
\end{abstract}

Keywords: Bank selection criteria, Retail banking, Iran

\section{Introduction}

Throughout the past decade structural, regulatory and technological factors have considerably changed the banking environment in Iran and resulted in intensified competition in the market place. The intense competition that exists in the banking industry services presents a big challenge to the profitability of retail banking institutions. Financial services marketing in Iran has become much more complex since privatization of public banks in the 2000s. Previously there tended to be significant demarcation between retail banks. However, the privatizations of retail banks, and a number of longer-term trends such as competition, technological advance, have led to the breaking down of the lines of demarcation. Consequently customers and their needs and their selection criteria become important for banks.

Exploring "How customers select banks" will help banks to identify the appropriate marketing strategies needed to attract new customers and retain existing ones (Kaynak and Kucukemiroglu, 1992). Resemblance of services offered by banks (Holstius and Kaynak, 1995) and greater than ever competition among retail banks have become more and more important. Therefore, banks should identify main factors that determine the basis upon which customers select retail banks.

Studies on retail bank marketing nowadays are not a new research concept. Literature review indicates that studies related to bank selection criteria have been mostly conducted in the USA and some European countries (Denton and Chan, 1991) and only few researches have been conducted in Iran. Some researchers believed that the banking services selection criteria in many countries are the same: price, reputation and service, there are, however, some differences in how Iranian customers understand these factors.

This study is part of a series of researches, carried out in 2011, on the retail banking industry in Tehran, capital city of Iran. There were two interrelated parts to the work: an exploratory customer survey that investigated issues relating to bank selection criteria and interviews with senior banking officials and bank customers to 
determine the important factors from their viewpoint, the current quantitative consumer study of bank selection criteria and prioritizing these criteria.

The main objectives in this research are:

1) To determine the criteria that Iranian's customer consider important when selecting a bank.

2) And how these criteria are prioritized according to their importance in order to better serve the customer needs.

\section{Literature Review}

The literature shows that the issue of bank selection criteria for broad categories of customers has been widely researched.

Kaufman (1967) examined the determinant factors used in bank selection decisions by customers and commercial firms in the USA. He found that the most significant factors reported by households were suitable location to home or place of business, length of bank-customers relationships and quality of services offered by the bank.

In another study, Mason and Mayer (1974) investigated the factors used by two groups of checking account customers in USA, high income and low income, in selecting their banks. Convenient location came on the top of the list. Other factors with high rankings were: friendly personnel; favorable loan experience; advice of friends; and influence of relatives.

Laroche, Rosenblatt and Manaing (1986) investigated 140 households in Montreal, Canada, to realize how people select their banks. In ranking the selection factors, findings show that friendliness of staff plays the important role in the bank selection process, followed by hours of operations, size of waiting lines, convenience of location, and efficiency of personnel.

In a study in South East Asia that was conducted by Tan and Chua (1986) who, using a small yet random sample of Singaporeans, found that, out of ten rated criteria, third party influences, namely family and friends, were the two most important influences relating to bank selection. Convenience of location was given a middle order ranking, while the speed of service delivery was ranked very low.

A study by Javalgi, Armaco andHosseini (1989) in the USA found that monetary factors are the main criteria in customers' bank selection decisions. Results of this study show that financial factors such as interest on savings accounts, safety of fund, and availability of loans have high scores. Other important factors were found to be convenient location and bank's reputation.

Erol, Kaynak and Elb dour Radi (1990) study was designed to find out the bank selection criteria used by customers of conventional and Islamic banks in Jordan. In general, factors which scored highly were: fast and efficient services, confidentiality of bank, bank's reputation and image, and friendliness of bank personnel.

Kaynak and Kucukemiroglu (1992) conducted a research in Hong Kong to find out the significance of selection criteria used by consumers in choosing banks. The major factors were reported to be convenient location, financial counseling, available parking space nearby, vault location, and loans and mortgages.

Haron, Ahmed and Planisek (1994) analyzed 301 Muslim and non-Muslim commercial bank customers in Malaysia to determine the selection criteria used in a dual banking environment. Results show that the highest scored factors are: speed of transactions, fast and efficient services, friendliness of bank personnel, and confidentiality of bank.

Boyd, Leonard and White (1994) used telephone survey to investigate the importance of 10 bank selection criteria in USA. In this study, the respondents were asked to rank, from the selected list of ten criteria. The ranking of bank selection criteria is: reputation, interest on savings accounts, interest charged on loans, quick service, location in city, hours of operation, availability of current accounts, friendliness of employees, modern facilities, drive-in service and other factors.

In a study by Holstius and Kaynak (1995), 258 bank customers in Finland were surveyed with the aim of determining the importance of selected criteria used by customers in choosing their banks. Results indicated that the main determinant factors for Finnish customers found to be: fast and efficient services, reception at the bank, friendliness of personnel, lower service charges and perceived confidentiality.

Yue and Tom's (1995) study was designed to find out the bank selection criteria used by Chinese-American customers residing in Sacramento, California. The most important factors were reported to be efficiency of services offered, bank's reputation, bank fees, convenient location, and interest rates on saving accounts and loans. 
Mylonakis, Malliaris and Siomkos (1998) studied 811 bank customers in the in Greece to spot the important bank selection criteria. The results indicated that selection factors scoring high were location convenience and quality of service (attention to customers, personalized service, no queues).

In another study, Bick and Brown (2004) examine the perception and expectations of banking customers regarding the value being delivered to them by retail banks in South Africa. The findings show that customers were not satisfied with the service, products and level of customer intimacy delivered to them by their banks. Thus, customers did not believe that they were getting the value they expected.

By using a survey of households, Omar and Orakwue (2006) evaluated the relative importance of bank selection criteria used by bank customers in Nigeria. The results suggest safety of fund and efficient of service and speed of transaction are the most important factors that customers considered when choosing their banks.

Blankson, Cheng and Spears (2007) investigate bank choice/selection criteria in a range of cultural and country economic scenarios. More specifically, they try to understand international consumers' selection criteria of banks in the USA, Taiwan, and Ghana. Results show that there is not very significance difference among these countries.

In another study, Rehman\& Ahmed (2008) analyze the major determinants of a bank selection by a customer in the banking industry of Pakistan. It is based on a survey of 358 customers of private, privatized and nationalized banks located in the city of Lahore (Pakistan). The results of the study reveal that the most important variables influencing customer choice are customer services, convenience, online banking facilities and overall bank environment.

In a study by Hinson, OwusuFrimpong and Dasah (2009), the importance of bank selection criteria was investigated. Data were collected from 2000 customers of 22 retail banks in Ghana. Results show that proximity is the most important factor from customers' view and recommendation by friends (word of mouth marketing) is least important factor.

A study by Al-Ajmi, Abo Hussain and Al-Saleh (2009) found that Islamic religious belief and social responsibility are the most important factors. 1000 questionnaires were distributed with response rate of 65.5 among customers who bank with conventional banks and Islamic banks in Bahrain. Results of the study reveal that cost benefit is the third most important factor considered in bank selection by Bahraini customers.

Rashid (2009) investigates selection criteria that influence Islamic banking in Bangladesh. Data were collected from 371 customers of 5 banks in Dhaka City. The results of the study show that the most important factors influencing customer bank selection are corporal efficiency, core-banking services and confidence.

Apart from studies that conducted generally and investigate the general banking selection criteria, many academicians focus on special group of people as a sample of study. For example, many researchers examined students banking selection criteria.

Lewis (1982) conducted a research on banking behavior among British students. A total sample of 716 students in 11 universities and colleges in England were surveyed for the study. Convenience of location to college and parental advice and influence were the predominant factors that were considered by students.

Khazeh and Decker (1993) surveyed the views of 209 university students in Maryland, USA to find out customers' bank selection criteria. The most important determinant criteria of bank selection identified in their study were service charge policy, reputation, interest charged on loans, quick loan approval and friendly tellers.

A study by Thwaites and Vere (1995), conducted in a Britain, showed that nearness of an ATM to university, free banking service and overall student offer were the most important selection criteria employed by college students in choosing which banks to patronize.

The study of Ma, Ng and Teo (1996) explained an investigation of the bank selection process using a sample of Singaporean graduates. Ma et al. study showed that the two most chief bank selection criteria were that the bank should provide a fast and efficient service and the bank should be financially stable.

Almossawi (2001) studied bank selection criteria being employed by college students in Bahrain. A total of 1,000 students aged 19-24 of the University of Bahrain served as a sample for the study. Findings show that the important factors determining college students' bank selection are: bank's reputation, friendliness of bank personnel, availability of parking space near the bank, and availability and location of automated teller machines (ATM).

Pass (2006) surveyed the views of 373 students from four community colleges and universities located in a large metropolitan area of the Western United States to find out what are the most important criteria that were used in bank selection decision process. Pricing and convenience were found to be the principal reasons for selecting a new bank. 
Mokhlis, Mat and Salleh (2008), in a study which sampled undergraduate students of Universiti Malaysia Terengganu, found that secure feelings, ATM service and financial benefits were of the most important criteria affecting their bank selection.

Rao and Sharma (2010) studied bank selection criteria being employed by MBA students in India. Data were collected form 312 students who have a bank account thorough questionnaire. Findings reveal that reliability is the most important factor in choosing a bank among students. Other significant factors are the responsiveness, value added services and convenience respectively.

The studies and researches reported in the literature review of the article indicate that banks can be successful by becoming customer-focused. This was approved by Driscoll (1999) who declared that customers choose banks based on five factors:

1 convenience;

2 price;

3 product selection (breadth and depth);

4 service; and

5 ambience (customers' experience).

A review of literature shows that the most studies related to bank selection criteria have been chiefly conducted in developed countries (Denton and Chan, 1991). Such studies have contributed significantly to the literature on bank selection criteria and helped researchers in developing the understanding of that but their findings may not be applicable to developing countries like Iran due to different cultural, ethnical, political and economic setup. Some factors that have an important role in bank selection in one country may prove to be unimportant in another (Almossawi, 2001).

\section{Research Methodology}

The current study was conducted in the city of Tehran (the largest city of Iran and its capital). All Iranian banks have many branch offices in this city. The data for the research was gathered from 798 customers of banks through a structured questionnaire covering the different attributes that customers perceive as important when selecting which banks to support. Given the nature of the study, a non-probability (convenience) sampling was chosen. The questionnaire was consisted of two sections.

In first part of questionnaire, respondents were asked to rate the relative importance of 38 influencing factors on their selection decision of commercial retail banks, using a five-point Likert type importance scale ranging from "very important" to "not important at all". The factors were extracted based on relevant literature and interviews with five bank officials and adopted to the Iranian banking system.

To get information about personal background of the respondents, questions regarding their gender, age, income level, education level, marital status and banking service usage included in the last part of the questionnaire.

To determine the potential effectiveness of the questionnaire and to check for potential problems with statement clarity, the survey instrument was pretested with 50 respondents. The subjects were asked if they had any suggestion or specific comments regarding the questions and structure of questionnaire.

A total of 830 questionnaires were distributed and 802 were returned, out of which 798 were considered usable (valid and completed), thereby yielding a response rate of about 96.1 percent. Such a response rate was considered sufficient for statistical reliability and generalizability.

\section{Findings (analysis and results)}

The responses to the bank selection criteria were analyzed using SPSS. As you can see in Table 1, 43.4 percent of respondents are between 18 to 30 years old. Of the 798 respondents, 43.4 percent were females and 56.6 percent were male. More than 50 percent of respondents have bachelor degree. The complete demographic of respondents can be seen in Tables 1, 2, 3 and 4 .

$$
\begin{aligned}
& \text { Insert Table } 1 \text { - Here } \\
& \text { Insert Table } 2 \text { - Here } \\
& \text { Insert Table } 3 \text { - Here } \\
& \text { Insert Table } 4 \text { - Here }
\end{aligned}
$$

In the first phase of data analysis, the importance ratings for the 38 evaluative criteria were factor analyzed to identify underlying dimensions in the set of bank selection criteria. SPSS was used to perform factor analysis on the responses to the bank selection criteria.Factor analysis is a technique which is used to "reduce a large number 
of variables to some smaller number by telling us which belong together and which seem to say the same thing" (Emory and Cooper, 1991).Factor analysis can be performed on an unrotated or rotated basis and there are different techniques available if we factor analysis is carried out on rotated basis. Among various techniques, varimax tends to be the preferred one for, as mentioned by Hair, Anderson and Black (1992), it "seems to give a clearer separation of the factors".Varimax-rotated factor analysis was performed on the constituent items representing the different constructs to validate empirically the theoretical structure of the scale. The Bartlett test of Sphericity is carried out and the Kaiser-Meyer Olkin (KMO) measure of Sampling Adequacy index is calculated. The results confirmed the appropriateness of the data for EFA (Exploratory Factor Analysis). The Kaiser-Meyer-Olkin (KMO) measure shows a value of 0.761(it is near 1.0) and the Bartlett's Test of sphericity also reaches statistical significance (0.000), supporting the factorability of the correlation matrix. Based on these results, Varimax-rotated factor analysis can be performed. Table 5 shows the result of KMO and Bartlett test.

\section{Insert Table 5 - Here}

Using the Eigenvalue greater than one rule, 11 factors were identified. All characteristics with factor loadings of 0.50 and above were retained. In addition, means were computed for all attributes retained within each factor to identify the relative importance of such attributes to the customers in their bank selection process. The mean of resulted Varimax rotation factors as well as Eigenvalues and percentage of variance are given in Table 6. In terms of overall factor means, the first factor is the most important in terms of bank selection and the eleventh factor is (marginally) the least important.

\section{Insert Table 6 - Here}

According to mean scores of factors, factor 2 (quality of service and availability of new banking methods) has the highest score (4.48) and factor 7 (additional services) has the lowest score (2.83). Additional services factor includes financial counseling and insurance services and type of a bank. In Iran, banks are public (owned by government) or private. Other factors according to their importance are: factor 8 (innovation and responsiveness), factor 11 (friendliness of staff and confidence in manager), factor 4 (price and cost), factor 9 (staff), factor 5 (convenience), factor 10 (satisfying credit needs), factor 3 (easy banking processes and variety of services), factor 1 (bank appearance) and factor 6 (reputation and word of mouth advertising).

Together the 11 factors explained more than half of the variance observed in the variables (68.65 percent), which satisfies the percentage of variance criterion for social science research (Hair, Anderson and Black, 1998).

In the second and final phase of the data analysis, to ascertain which of the banking selection criteria are perceived as more or less important, the Friedman Test was performed to rank all the 11 factors. Friedman Test is a non-parametric alternative to the one-way repeated measures analysis of variance. It is more suitable when measurement of the variables is in an ordinal scale (Norusis, 2004). SPSS was also used to carry out Friedman Test.The means ranks of all the factors are calculated that confirmed the mean scores of factors. Table 7 and 8 show the results of Friedman analysis.

$$
\begin{aligned}
& \text { Insert Table } 7 \text { - Here } \\
& \text { Insert Table } 8 \text { - Here }
\end{aligned}
$$

Among top four factors, one can observe that "quality of service and availability of new banking methods" play a significant role in bank customers' decision making process. Responsiveness of staff and their attitude and cost of banking services are also employed by customers when they want to choose which bank to patronize.

It is worth noting that although factors such as reputation and word of mouth advertising are considered important by bank customers in other countries, Iranian bank customers ignore these two factors in their decision making process. This finding is contrary to other studies findings (e.g. Mason et al., 1974; Tan et al., 1986; Javalgi et al., 1989; Erol et al., 1990; Khazeh et al., 1993; Yue et al, 1995; Almossawi, 2001; Hinson et al., 2009) which emphasize on reputation and word of mouth advertising as important factors.

Since no similar research has been conducted in Iran, we can compare the findings of this study with those of other studies which are conducted in neighbor countries. Iranian people have many common cultural roots with people in middle-east such as Bahrain and Pakistan. Middle-eastern bank customers show similar behavior in their decision making process.

Bank customers in Iran and Pakistan emphasize on three common and important factors as bank selection criteria: customer services, convenient of ATM locations and on-line banking services (new methods of banking) (Rehman and Ahmed, 2008). Although there are common factors among bank customers when they choose their bank, there are differences between Iranian and Pakistani customers' selection criteria. Cost and price of banking services play a key role in Iranian bank customers' decision making while Pakistani customers consider this factor as little as important (Rehman and Ahmed, 2008). 
Iranian bank customers have many common cultural roots with Bahraini bank customers. The highly scored common factor between Iranian and Bahraini customers was reported to be only"convenient ATM locations". While these groups (Iranian and Bahraini customers) have only one commonality in important factors, they do not consider factors such as "recommendation by friends" and "recommendation by relatives" important when they choose their banks (Almossawi, 2001). Bahrainis put more importance on factors such as "bank's reputation and image" while Iranian counterparts consider this factor unimportant (Almossawi, 2001).

In line with other related studies (e.g. Laroche et al., 1986; Erol et al., 1990; Khazeh et al, 1993; Haron et al., 1994, Boyd et al., 1994; Holstius et al., 1995; Almossawi, 2001) "friendliness of staff" was found to play a major role as a selection criterion. One of the most important factors which Iranian bank customers consider important and employ it in their decision making process in comparison with other nations' is "innovation and responsiveness".

\section{Conclusion}

The purpose of this research is to determine the important factors that bank's customers perceive as useful to their selection of retail banks in Iran. The importance of this study can be seen from two perspectives: theoretical and practical. Theoretically, this study fills an important gap in the literature, which is, investigating bank selection criteria for customers in the Iran. As a result, the findings of this study can add to the limited body of knowledge in the bank marketing literature and can serve as a starting point on which future studies can be built. On the practical side, this study can assist bank managers to identify the important factors that may determine bank selection decisions among customers. Such information should help the management of banks in devising suitable marketing strategies for reaching, attracting and retaining customers.

Findings from this study reveal that bank customers place more emphasis on factors such as quality of services, innovation in banking services, staff's behavior and attitudes and price. Therefore, Managers of commercial retail banks should consider above mentioned factors seriously in designing their marketing strategies.

The results of factor analysis reveal the importance of a factor: innovation. Of the respondent 47.6 percent are between 18 to 30 years old. These groups of customers like new technologies and used them in their daily activities. Banks should set up many kinds of hi tech-services such as Internet banking, SMS banking, email banking and phone banking to attract new customers and retain their existing customers.

In addition, banks have to understand the customer needs and wants and try to increase satisfaction level of customers by providing tailor made services. Finally, in today's era bank customers require personalized and value added services such as e-banking because they do not want to spend their valuable time in bank branches.

One limitation of this study is the fact that the questionnaires were distributed only in one city (Tehran). As the survey conducted was only confined to Tehran region results may vary if research is in conducted in other Cities of Iran. Customers in other regions may have different selection criteria according to their cultures and ethnic groups that they belong. It would be interesting to investigate the applicability of the findings by replicating similar studies in other cities.

\section{References}

Al-Ajmi, J., Abo Hussain, H., and Al-Saleh, N. (2009). Clients of conventional and Islamic banks in Bahrain: How they choose which bank to patronize. International Journal of social Economics, 36(11). http://dx.doi.org/10.1108/03068290910992642

Almossawi, M. (2001). Bank selection criteria employed by college students in Bahrain: an empirical analysis. International Journal of Bank Marketing, 19(3), 115-25. http://dx.doi.org/10.1108/02652320110388540

Bick, G., Brown, A. B., and Abratt, R. (2004). Customer perceptions of the value delivered by retail banks in South Africa. International Journal of Bank Marketing, 25(5), 300-318. http://dx.doi.org/10.1108/02652320410549638.

Blankson, C., Ming-sung C. J., \& Spears, N. (2007). Determinants of banks selection in USA, Taiwan and Ghana. International Journal of Bank Marketing, 25(7), 469-489. http://dx.doi.org/10.1108/02652320710832621.

Boyd, W., Leonard, M., and White, C. (1994). Customer preferences for financial services: an analysis. International Journal of Bank Marketing, 12 (1), 9-15. http://dx.doi.org/10.1108/02652329410049562.

Denton, L., and Chan, A.K.K. (1991). Bank selection criteria of multiple bank users in Hong Kong. International Journal of Bank Marketing, 9 (4), 23-34. http://dx.doi.org/10.1108/02652329110007129.

Driscoll, J. (1999). Bank wars: episode 2. The branches strike back. Bank Marketing, 31 (12), 22-30.

Emory, C.W., and Cooper, D.R. (1991). Business Research Methods, Irwin, Burr Ridge, IL. 
Erol, C., Kaynak, E., and El-B dour Radi. (1990). Conventional and Islamic banks: patronage behavior of Jordanian customers. International Journal of Bank Marketing, 8 (4), 25-35. http://dx.doi.org/10.1108/02652329010004231.

Hair, J.F. Jr, Anderson, R.E., Tatham, R.L., and Black, W.C. (1992). Multivariate Data Analysis with Readings. (3rd ed.). Maxwell.

Hair, J.F. Jr., Anderson, R.E., Tatham, R.L., \& Black, W.C. (1998). Multivariate Data Analysis, (5th Edition). Upper Saddle River, NJ: Prentice Hall.

Haron, S., Ahmed, N., and Planisek, S. (1994). Bank patronage factors of Muslim and non-Muslim customers. International Journal of Bank Marketing, 12 (1), 32-40. http://dx.doi.org/10.1108/02652329410049599.

Hinson, R., Owusu-Frimpong, N., and Dasah, J. (2009). Key motivations for bank patronage in Ghana. International Journal of Bank Marketing, 27 (5), 381-399. http://dx.doi.org/10.1108/02652320910979898.

Holstius, K., and Kaynak, E. (1995). Retail banking in Nordic countries: the case of Finland. International Journal of Bank Marketing, 13(8), 10-20. http://dx.doi.org/10.1108/02652329510098873.

Javalgi, R.G., Armaco, R.L., and Hosseini, J.C. (1989). Using the analytical hierarchy process for bank management: analysis of consumer selection decisions. Journal of Business Research, 19, 33-49. http://dx.doi.org/10.1016/0148-2963(89)90039-8.

Kaufman, G.G. (1967). A Survey of Business Firms and Households View of a Commercial Bank, Report to the Federal Reserve Bank of Chicago, Appleton, University of Wisconsin, Madison, WI.

Kaynak, E., and Kucukemiroglu, O. (1992). Bank and product selection: Hong Kong. International Journal of Bank Marketing, 10 (1), 3-16. http://dx.doi.org/10.1108/02652329210007858.

Khazeh, K., and Decker, W. (1993). How customers choose banks. Journal of Retail Banking, 24 (4), 92-93.

Laroche, M., Rosenblatt, J.A., and Manaing, T. (1986). Services used and factors considered important in selecting a bank: an investigation across diverse demographic segments. International Journal of Bank Marketing, 4 (1), 35-55. http://dx.doi.org/10.1108/eb010771.

Lewis, B.R. (1982). Student accounts \pm a profitable segment? European Journal of Marketing, 16 (3), 63-72.

Ma, K.Y., Ng, B.K., and Teo, C.S. (1996). Bank selection criteria and the practice of multiple banking among degree holders in Singapore. BBus dissertation, Nanyang Technological University, Singapore.

Mason, J.B., and Mayer, M.L. (1974). Differences between high-and-low-income savings and checking account customers. The Magazine of Bank Administration, 65, 48-52.

Mokhlis, S., Mat, N.H.N., and Salleh, H.S. (2008). Commercial Bank Selection: The Case of Undergraduate Students in Malaysia. International Review of Business Research Papers, 4 (5), 258-270.

Mylonakis, J., Malliaris, P., and Siomkos, G. (1998). Marketing-driven factors influencing savers in the hellenic bank market. Journal of Applied Business Research, 14 (2), 109-16.

Norusis, M.J. (2004). SPSS 12.0: Guide to Data Analysis. Prentice Hall, Englewood Cliffs, NJ.

Omar, O., \& Orakwue, E. (2006). Gender-based choice of retail banking in Nigeria.Journal of Business \& Retail Management Research (JBRMR), May 2006.

Pass, M.W. (2006). Western US college students: banking preferences and marketplace performance. Journal of Financial Services Marketing, 11, 49-63. http://dx.doi.org/10.1057/palgrave.fsm.4760016.

Rao, S., and Sharma R. K. (2010). Bank Selection Criteria Employed by MBA Students in Delhi: An Empirical Analysis. Journal of business studies Quarterly, 1 (2), 56-69.

Rashid, M. (2009). Customer Demographics Affecting Bank Selection Criteria, Preference, and Market Segmentation: Study on Domestic Islamic Banks in Bangladesh. International journal of Business and Management, 4(6).

Rehman, H., \& Ahmed, S. (2008). An empirical analysis of determinants of bank selection in Pakistan: a customer view. Pakistan Economic and Social Review, 46 (2).

Tan, C.T., and Chua, C. (1986). Intention, attitude and social influence in bank selection: a study in an oriental culture. International Journal of Bank Marketing, 4 (3), 43-53. http://dx.doi.org/10.1108/eb010783.

Thwaites, D., \& Vere, L. (1995). Bank selection criteria: A student perspective. Journal of Marketing Management, 11(1-3), 133-149. http://dx.doi.org/10.1080/0267257X.1995.9964334.

Yue, H., and Tom, G. (1995).How the Chinese selects their banks. Journal of Retail Banking, 26 (4). 
Table 1. Age of respondents

\begin{tabular}{|l|c|c|}
\hline & Frequency & Percent \\
\hline Under18 & 31 & 3.9 \\
\hline $18-30$ & 380 & 47.6 \\
\hline $31-42$ & 261 & 32.7 \\
\hline $43-54$ & 74 & 9.3 \\
\hline Above 55 & 52 & 6.5 \\
\hline Total & 798 & 100.0 \\
\hline
\end{tabular}

This table lists age of respondents who filled questionnaire

Table 2. Gender of respondents

\begin{tabular}{|l|c|c|}
\hline & Frequency & Percent \\
\hline Male & 452 & 56.6 \\
\hline Female & 346 & 43.4 \\
\hline Total & 798 & 100.0 \\
\hline
\end{tabular}

This table shows number and percentage of respondents' gender.

Table 3. Marital Status of Respondents

\begin{tabular}{|l|c|c|}
\hline & Frequency & Percent \\
\hline Married & 427 & 53.5 \\
\hline Single & 371 & 46.5 \\
\hline Total & 798 & 100.0 \\
\hline
\end{tabular}

This table shows the marital status of respondents.

Table 4. Education level of respondents

\begin{tabular}{|l|c|c|}
\hline & Frequency & Percent \\
\hline Diploma-under diploma & 180 & 22.6 \\
\hline Bachelor & 426 & 53.4 \\
\hline Master or PhD & 192 & 24.1 \\
\hline Total & 798 & 100.0 \\
\hline
\end{tabular}

This table listseducation level of respondents who filled questionnaire

Table 5. KMO measure and Bartlett's test

\begin{tabular}{|l|l|l|}
\hline & $\begin{array}{c}\text { Kaiser-Meyer-Olkin Measure of } \\
\text { Sampling Adequacy }\end{array}$ & .706 \\
\hline Bartlett's Test of Sphericity & Approx. Chi-Square & $1.546 \mathrm{E} 4$ \\
\hline df & 703 \\
\hline Sig. & .000 \\
\hline
\end{tabular}

This table shows KMO measure and Bartlett's test results and they confirmed the adequacy of samples for using factor analysis. 
Table 6. Mean Score of Factors

\begin{tabular}{|c|c|c|c|c|c|}
\hline Factors & variables & Mean & $\begin{array}{c}\text { STD. } \\
\text { Deviation }\end{array}$ & Eigenvalues & $\begin{array}{c}\text { Percentage of } \\
\text { variance }\end{array}$ \\
\hline $\begin{array}{l}\text { Factor 1 (Bank } \\
\text { Appearance) }\end{array}$ & $\begin{array}{l}\text {-External appearance of bank } \\
\text {-Interior design of bank } \\
\text { - Pleasant bank atmosphere and sufficient } \\
\text { facilities } \\
\text { - Sitting Arrangements }\end{array}$ & 3.7243 & .70508 & 6.861 & 18.055 \\
\hline $\begin{array}{l}\text { Factor } 2 \text { (quality } \\
\text { of services and } \\
\text { availability of } \\
\text { new banking } \\
\text { methods) }\end{array}$ & $\begin{array}{l}\text { - Convenient ATM locations } \\
\text { - Accuracy of services Transactions } \\
\text { - Quality of Customer Services } \\
\text { - Provision of fast and efficient service } \\
\text { - Availability of different types of new } \\
\text { banking methods (internet banking, SMS } \\
\text { banking, E-mail banking, etc.) }\end{array}$ & 4.4825 & .47351 & 3.492 & 9.190 \\
\hline $\begin{array}{l}\text { Factor } 3 \text { (easy } \\
\text { banking } \\
\text { processes and } \\
\text { variety of } \\
\text { services) }\end{array}$ & $\begin{array}{l}\text { - Involved in the community (e.g. giving } \\
\text { donations, scholarships)Environmental } \\
\text { practice and impact } \\
\text { - Advertisement } \\
\text { - Ease of opening a current account } \\
\text { - Ease of obtaining loans } \\
\text { - Variety of services offered } \\
\text { - Availability of different banking cards } \\
\text { (debit, credit, etc.) }\end{array}$ & 3.8701 & .57533 & 2.881 & 7.581 \\
\hline $\begin{array}{l}\text { Factor } 4 \text { (price } \\
\text { and cost) }\end{array}$ & $\begin{array}{l}\text { - Reduction of queuing time } \\
\text { - Bank charges competitive prices for } \\
\text { products and services } \\
\text { - Paying highest interest rates on saving } \\
\text { accounts } \\
\text { - Low interest rates on loans }\end{array}$ & 4.2453 & .63788 & 2.441 & 6.423 \\
\hline $\begin{array}{l}\text { Factor } 5 \\
\text { (Convenience) }\end{array}$ & $\begin{array}{l}\text { - Bank is located in a convenient location } \\
\text { for customer } \\
\text { - Availability of Several branches } \\
\text { - Hours of operation } \\
\text { - Friday banking(offering services in } \\
\text { weekends) } \\
\text { - Available parking space nearby }\end{array}$ & 4.0318 & .51060 & 2.293 & 6.034 \\
\hline $\begin{array}{l}\text { Factor } 6 \\
\text { (Reputation and } \\
\text { word of mouth } \\
\text { advertising) }\end{array}$ & $\begin{array}{l}\text { - Bank has a strong reputation and good } \\
\text { image in the community } \\
\text { - Recommendation by friends } \\
\text { - Recommendation by relatives }\end{array}$ & 3.4478 & .75085 & 1.625 & 4.276 \\
\hline $\begin{array}{l}\text { Factor } 7 \\
\text { (additional } \\
\text { services) }\end{array}$ & $\begin{array}{l}\text { - Type of bank (public or private) } \\
\text { - Offering Financial counseling } \\
\text {-Providing different insurance services }\end{array}$ & 3.3392 & .80495 & 1.532 & 4.031 \\
\hline $\begin{array}{l}\text { Factor } 8 \\
\text { (innovation and } \\
\text { responsiveness) }\end{array}$ & $\begin{array}{l}\text { - Bank is innovative and provides } \\
\text { customer with new ideas/products and } \\
\text { uses current/new technology } \\
\text { - Responsiveness of bank staff }\end{array}$ & 4.3540 & .61886 & 1.421 & 3.739 \\
\hline Factor 9 (staff) & $\begin{array}{l}\text { - Appearance and attire of staff } \\
\text { - Knowledgeable and competent staff }\end{array}$ & 4.1598 & .62905 & 1.292 & 3.401 \\
\hline $\begin{array}{l}\text { Factor } 10 \\
\text { (satisfying credit } \\
\text { needs) }\end{array}$ & $\begin{array}{l}\text { - Bank is willing to accommodate } \\
\text { customer credit needs }\end{array}$ & 4.0301 & .82866 & 1.175 & 3.093 \\
\hline Factor 11 & $\begin{array}{l}\text { - Friendliness of bank staff } \\
\text { - Confidence in bank manager }\end{array}$ & 4.2901 & .47995 & 1.075 & 2.830 \\
\hline
\end{tabular}


Table 7. Friedman Analysis Test Statistics

Table 8. Ranks of Factors

\begin{tabular}{|l|c|}
\hline $\mathrm{N}$ & 798 \\
\hline Chi-Square & $2.335 \mathrm{E} 3$ \\
\hline df & 10 \\
\hline Asymp. Sig. & .000 \\
\hline
\end{tabular}

\begin{tabular}{|l|c|}
\hline \multicolumn{1}{|c|}{ Factors } & Mean Rank \\
\hline Factor 2 & 8.58 \\
\hline Factor 8 & 7.85 \\
\hline Factor 11 & 7.32 \\
\hline Factor 4 & 7.12 \\
\hline Factor 9 & 6.69 \\
\hline Factor 5 & 6.06 \\
\hline Factor 10 & 6.12 \\
\hline Factor 3 & 5.06 \\
\hline Factor 1 & 4.62 \\
\hline Factor 6 & 3.45 \\
\hline Factor 7 & 7.32 \\
\hline
\end{tabular}

This table shows the rank of factors and their mean rank scores. 